\title{
CRIMES DE RACISMO ANALISADOS NOS TRIBUNAIS BRASILEIROS: 0 que as características das partes e os interesses corporativos da magistratura podem dizer sobre o resultado desses processos
}

\section{重 Cleber Lazaro Julião Costa}

\section{Palavras-Chave}

Racismo/ Processos de racismo/ Hierarquia Social/Interesses dos juízes

\section{SUMÁRIO}

1. Introdução; 2.0 mapa dos processos de racismo: a tendência pela absolvição a partir do trato quantitativo.

3. Explicando a tendência pela perspectiva da figura da hierarquia; 4. O mundo dos juízes e o seu impacto nos processos de racismo; 5 . Conclusão.

\section{Resumo}

Este texto faz um estudo do papel de elementos não jurídicos e jurídicos em benefício dos réus acusados de discriminação racial nas Cortes brasileiras. O estudo foca na análise de 97 decisões penais de Cortes brasileiras. Recentemente, a democracia brasileira testemunhou importantes mudanças, tais como a criminalização da discriminação e do racismo. Estas mudanças são resultado da luta realizada pelo Movimento Negro na busca de direitos civis em mais de três décadas, apesar de a sociedade brasileira historicamente negar a

Doutor em Sociologia pelo IESP/UERJ, Mestre em Sociologia pelo IUPERJ/UCAM e Bacharel em Direito pela UCSAL. Professor da Universidade do Estado da Bahia do Curso de Ciências Sociais na disciplina de Ciência Política, Campus Salvador. Coordenador do Grupo de Pesquisa em Instituições e Desigualdades. existência de discriminação contra a população negra. O início dos processos raciais permitiu a possibi- lidade de pesquisas interessadas em verificar se as vítimas de racismo tinham boas chances de vitória ou se elas não tinham sucesso em seus casos. Da análise dessas decisões, verifi- cou-se que os atos discriminatórios contra ví- timas negras não eram considerados racismo (crime inafiançável e contra toda a humanida- de) e sim crime de injúria, tipo penal que não reúne as mesmas características da previsão constitucional, por outro lado, quando eram praticados contra judeus tinham o tratamento do tipo penal previsto na Constituição de 1988. Esta constatação gerou a inquietação se a análise de elementos sensíveis ao social, como raça/cor e ocupação poderiam ajudar na tentativa de explicar a diferença de vitórias entre vítimas e réus. Também se os juízes eram orientados por algum interesse, como mais trabalho ou menos trabalho, se optassem por condenar ou absolver. Para o desenvolvimento deste texto, a pesquisa dirigiu atenção às decisões judiciais, entre 2005 e 2012, buscando construir padrões explicativos sobre as posições dos juízes sobre racismo e quais recursos usam para fundamentar as suas decisões. 


\section{RACISM CRIMES IN THE \\ BRAZILIAN COURTS:}

what can the interests of the parties and

the corporate interests of the judges tell

about the outcomes of these proceedings

\section{Keywords}

Racism / Racial Trials / Social Hierarchy / Judges Interests

\section{Abstract}

This paper scrutinizes the role of non- legal and legal elements work out to the benefit of defendants on charged of racial discrimination at the judicial trials in Brazilian Courts. The study aims to analyze 97 penal decisions from the Brazilian Courts. Recently, the Brazilian democracy witnessed important changes, such as the criminalization of the racial discrimination andracism. Thesechangeswerearesultofthe Black Movement struggle for Afro Brazilian civil rights over the last three decades, despite the society historical discourse to denying the existence of discrimination against black people due their race/color. The beginning of race trials could contribute for the development of researches interested to verify if the victims of racism have had good chance of victory or if they have not had success. On regarding those decisons, the discriminatory acts against the victims were not considered racism (a non- bailable felony, and a crime against the whole humanity), but another kind of crime called injuria that does not gather the same essence of the constitutional provision. This conclusion raised a question whether the analysis of sensitive social elements, such as race/color, and occupation levels could explain difference of victory between the victims and the defendants. Furthermore, if the judges were guided by some kinds of interests, such as more work or less work when they choose by to convict or acquit. For development of this text, the research aimed to the judicial decisions between 2005 and 2012, seeking to build explained patterns upon judges' stands about racism, and which sources they worked on to support their decisions. 


\section{INTRODUÇÃO}

O Judiciário adquiriu na estrutura sociopolítica brasileira papel relevante com a Constituição promulgada de 1988. A partir da organização de um sistema de controle difuso e concentrado de constitucionalidade, bem como a implementação de direitos coletivos e garantindo o devido processo legal, o Poder Judiciário viu suas atribuições serem ampliadas (Vianna, Carvalho, Melo \& Burgos, 1999), gerando novas expectativas de funcionamento na tentativa de contribuir para o exercício cívico da população.

$\mathrm{Na}$ esfera das relações raciais, o Movimen- to Negro enxergou a criminalização do ra- cismo como uma forma de objetar práticas ofensivas, discriminatórias e segregacionistas (Caó, 1988) potenciais à manutenção da condição socioeconômica marginal da população negra que the impunha um status de cidadania de segunda classe. Assim, o estabelecimento de um sistema antirracis- ta de esfera penal, a partir da criminalização prevista no artigo 50, inciso XLII na Constituição de 1988, deu impulso à estratégia de processar demandas no âmbito judicial, visando a condenação de supostas agressões de cunho racial.

Esta nova realidade abriu um campo de pesquisa para os cientistas sociais que estudam desigualdades e atuação estatal quanto ao desejo de mitigá-las, ampliando o raio de análise para a esfera do Judiciário. Neste sentido, a primeira inquietação dos pesqui-

sadores $^{1}$ residiu em aferir qual o score na corrida processual.

Saber quem ganha mais, se vítimas de racismo ou réus, parte da ideia de ambos te- rem, supostamente, as mesmas chances de êxito, afinal a disposição processual leva em conta condições iguais entre as partes. Neste sentido, cabe as partes e, sobretudo, aquela que propõe ação trazer provas aos autos que possam provar o alegado, pois em caso de dúvida, a ordem jurídica penal brasileira acolhe a presunção da inocência (Greco, 2007).

Se outras agências estatais dispõem de bancos de dados $^{2}$ acessíveis para que pesquisadores possam analisar as políticas desenvolvidas e o seu impacto por diversos olhares, o Judiciário ainda mantém de forma mais cerrada suas realizações apesar de tímidos avanços protagonizados pelo Conselho Nacional de Justiça ${ }^{3}$. Este órgão, instalado em 2005, tomou algumas medidas importantes, como a unificação numérica dos processos, produziu o censo do corpo funcional do Judiciário, entre outras medidas que ajudam a construir argumentos e considerações sobre ação do Judiciário na dinâmica política brasileira, bem como em demandas que têm caráter mais específico, a exemplo das levantadas pelo Movimento Negro quanto à diminuta presença de magistrados de cor preta e parda em relação ao contingente populacional geral ${ }^{4}$.

A dificuldade de acessar os dados do Judiciário exigiu a criação de estratégias para o levantamento de informações que pudessem embasar estudos sobre o resultado dos processos de racismo. Com o advento da internet e o uso das ferramentas de consul-

cortes brasileiras, bem como a fundamentação legal desenvolvida. 
Revista de Estudos Empíricos em Direito

${ }^{2}$ A título de ilustração, para questões de registro de morbidade, há o DATASUS; para identificação do perfil (raça/cor e sexo) de trabalha- dores cujos contratos de trabalho são regulados pela CLT, há a RAIS, dentre outros.

${ }^{3}$ http://www.cnj.jus.br/

${ }^{4}$ Segundo o censo do Conselho Nacional de Justiça (BRASIL, 2014, p. 41 ), o número de juízes pretos é $1,5 \%$ e de pardos $14,2 \%$, enquanto de brancos $82,2 \%$. Levando-se em conta que em 2014, segundo o IBGE (2015) 53,6\% da população brasileira se declarou ou preta ou parda, vê-se que há uma sub-representação da população negra nos cargos da magistratura nacional. 
tas dos processos pelos sites dos Tribunais, iniciou-se o trabalho de levantamento dos processos por meio do sistema de busca existente nos Tribunais. Estes oferecem ao usuário um banco de jurisprudência para a consulta dos julgados por termos e expressões. Este mecanismo é cotidianamente usado pelos (as) profissionais do direito para verificar o entendimento de determinado tribunal sobre um tema em específico.

O sistema de busca Jurisprudência dos tribunais corresponde a um mecanismo acessível aos (às) profissionais para se orientarem acerca dos julgados. Ora, se eram base para a confecção de teses pelo lado dos atores judicantes, haveriam de ter serventia para o pesquisador interessado na análise de casos de racismo. Para o levantamento desses processos penais em todo o país, foram usadas as palavras (racismo, preconceito e injúria)e expressões (preconceito racial e injúria racial ou qualificada), visando o mapeamento da atuação do judiciário nos casos de racismo.

A possibilidade de levantar processos de racismo nos tribunais brasileiros permitiu a criação de um banco de dados. Construiu-se um questionário com 46 itens organizados em oito grupos: 1)localização do processo; 2) informações da tramitação de 20 grau; 3 ) informações sobre o processo de 10 grau; 4 ) informações quanto à existência de decisões disponíveis; 5) informações sobre vítima;6) sobre o réu; 7) qual o artigo que fundamentou o pedido; e 8) o resultado. Com o volume de informações ascendendo, um banco de dados foi criado e que está hospedado na rede mundial de computadores denominado Sistema Juris ${ }^{5}$.

${ }^{5}$ O Sistema Juris foi criado em 2007 e, inicialmente, foi hospedado no servidor do Laboratório de Análises Estatísticas, Econômicas e Sociais

do Instituto de Economia da UFRJ. Desde o final de 2018, está hospedado no site da Universidade do Estado da Bahia e sendo reestruturado para abrigar processos de novos biênios. A montagem de um sistema virtual permitiu e continua permitindo que o Sistema seja
A pesquisa das ementas das decisões dos tribunais deu condições a um processo de garimpagem de informações. Isto pela ra-zão de muitas vezes as informações esta- rem em diversos locais do sistema virtual dos tribunais. Assim, das ementas das deci-sões, tentava-se chegar aos históricos de andamentos, bem como informações relativas à natureza da ação, quem havia interposto o recurso, datas de sua interposição, entre outros. Igualmente, por meio destes dados iniciais, alguns dados relacionados à primeira instância eram encontrados, aumentando o número de informações para cada processo encontrado. O levantamento dos dados processuais permitiu que o Sistema Juris fosse alimentado, liberando a confecção dos primeiros quadros de análise sobre o tipo de ação judicial e o resultado dessas demandas. A conclusão obtida revelou a tendên- cia dos tribunais em absolver mais do que condenar quando se tratava de processos penais (Costa, 2008 e Costa \& Carvano, 2011).

Outrossim, os dados quantitativos inicialmente produzidos suscitaram a necessidade de estudo das decisões que foram encontradas não em sua totalidade, mas que também, do ponto de vista estatístico, assemelhavam-se, quanto ao resultado final, com a análise sobre os processos. Isto porque os dados disponíveis no Sistema Juris traduzem a dinâmica de categorias como vitória do réu ou vitória da vítima e respectivos cruzamentos pelo trato quantitativo. Apesar de riqueza de informações, apenas com a análise das decisões que variáveis, como raça/cor e ocupação, puderam ser identificadas e ajudar no entendimento da atuação judicial em casos de racismo em processos penais.

alimentado em qualquer lugar e com atualização de informações 
Revista de Estudos Empíricos em Direito

Brazilian Journal of Empirical Legal Studies

vol. $6, n^{\circ}$ 3, dez 2019, p. 7-33

imediatas, bem como a produção de relatórios em formato Excel para análises dos dados coletados. É a principal ferramenta estatística uti- lizada pelo autor para organização e tabulação dos dados coletados nos sites dos tribunais pesquisados para análise de trato estatístico. 
O estudo das decisões parte do questionamento quanto à possibilidade de compreender a tendência dos juízes em absolver mais do que condenar a partir da atenção aos elementos não jurídicos (raça/cor e ocupação). As condições das partes influenciam no processo de decidibilidade judicial cuja tendência, em casos de racismo, compreende absolver réus em vez de condená-los? Outro ponto do trabalhado diz respeito em saber se a tendência pela absolvição, quando seguida pelo (a) juiz (a), redunda em menos trabalho e a dissidência, pelo contrário, mais esforço. A tendência dos tribunais em absolver os réus influencia os (a) juízes em fazer a escolha pela absolvição? O que os recursos (prova, jurisprudência e doutrina) usados nas decisões podem explicar quanto à medida de mais ou menos esforço?

Assim, o presente estudo está dividido em três seções além desta introdução e da conclusão. Na seção 2, está elaborado o quadro de resultado dos processos penais entre 2005 e 2012 no Brasil, bem como informações relativas às partes e à natureza dos processos. Estas informações são a matéria prima para as seções seguintes. Na três, a tendência apresentada na seção anterior é analisada pelas lentes da figura das características das partes em que se infere ahierarquia como um potencial elemento motivador para a ação racista e para o resultado final dos processos. Neste sentido, a discussão também articula o conceito de racismo à brasileira e o termo democracia racial. A última seção trata da figura dos juízes como servidores públicos e não como a personificação da justiça. Isto implica analisar o comportamento judicial por vieses pautados em

interesse profissional e pessoal, a partir da articulação dos recursos disponíveis e usados pelo juiz, buscando compreender se a tendência dos tribunais em absolver reflete na potencial escolha do (a) juiz.

\section{O MAPA DOS PROCESSOS DE RACISMO: A TENDÊNCIA PELA ABSOLVIÇÃO A PAR- TIR DA ANÁLISE QUANTITATIVA}

Encontrar processos sobre racismo nos tribunais brasileiros é uma tarefa difícil face à ausência de dados oficiais consolidados. Esta barreira quase intransponível, dado aos elevados custos de dirigir-se a cada unidade da federação para acessar os processos, foi superada de certa forma à medida que o processo de informatização adquiriu musculatura no sistema funcional da agência judicial.

Assim, a internet viabilizou a coleta de informações substituindo a logística tradicional caracterizada pelas viagens para as sedes dos tribunais. Por outro lado, a pesquisa desenvolvida por meio da tela do computador e do uso da internet depara com outrasnecessidades, como a de ter boa velocidade de navegação, diferentes máquinas atualizadas e uma quantidade delas para que o IP6 não fique visado pelos sistemas de monitoramento dos sites oficiais da Justiça, que têm criado mecanismos de controle para evitar acessos por robôs.

Igualmente, a construção de uma base de dados virtual, como o Sistema Juris, exige a parceria com profissionais de programação, bem como a manutenção do site e na confiança do local onde ele está hospedado para que não haja violação do sistema e perda de informações (atualmente o Sistema Juris está hospedado no site da Universida-

${ }^{6}$ A sigla IP significa Protocolo da Internet do inglês Internet Protocol. É um identificador para cada dispositivo conectado à rede de computadores.

CRIMES DE RACISMO ANALISADOS NOS TRIBUNAIS

BRASILEIROS: o que as características das partes e os interesses corporativos da magistratura podem dizer sobre o resultado desses processos

Cleber Lazaro Juilião Costa 
de do Estado da Bahia). A pesquisa pautada pelas redes de computadores ganha, assim, novos desafios e referências de atuação, fazendo com que a necessidade de trocas entre áreas de conhecimento distintas seja uma realidade cotidiana.

Inicialmente, a organização dos processos para aferição da distribuição dos resultados partiu da unificação por anos. O primeiro levantamento de dados foi iniciado em outubro de 20077 e concluído em dezembro do mesmo ano, e a meta era compilar processos do ano mais remoto a partir da promulgação da lei 7.7168 de 5 de janeiro de 1989, norma em que está regulamentada a criminalização do racismo pela Constituição de 1988. Mais dois levantamentos foram feitos: o período de março de 20109 a dezembro de 2010 e o último de outubro de 2012 a julho de 201310.

Certamente, as limitações tecnológicas para aquele período tão remoto seriam sen- tidas com um número ínfimo de processos disponíveis na web em todas as regiões. Esta hipótese se confirmou, havendo pou- cos processos entre 1997 e 2004. O levantamento sempre foi feito em biênios, ou seja, a abrangência de análise teria como base o período de 24 meses em que os processos fossem julgados em 2a instância. Os períodos sob análise compreendem 2005/2006, 2007/2008, 2009/2010, 2011/2012.

Foram encontrados 149 processos penais que haviam transitado em julgado e cujas ementas estavam disponíveis por meio da busca nas janelas Jurisprudências. Aolongo

\footnotetext{
Em 2007, levantamento dos processos penais do biênio 2005/2006 dos tribunais de justiça. Cf. COSTA, 2008).

${ }^{8}$ Cf. http://www.planalto.gov.br/ccivil_03/LEIS/L7716.htm

${ }^{9}$ Em 2010, levantamento dos processos penais dos biênios 2005/2006 e 2007/2008 dos tribunais de justiça. Cf. Costa e Carvano, 2011).

${ }^{10} \mathrm{Em} \mathrm{2013}$, atualizei os processos que já estavam no Sistema, incluindo decisões. Também levantei processos do biênio 2009/2010 e 2011/2012.
}

de 4 biênios pesquisados nos 26 tribunais estaduais e 1 Distrital, a distribuição dos processos ficou estabelecida conforme o gráfico 1 abaixo:

Gráfico 1: Evolução dos processos penais levantados nos sites dos TJs entre 2005 e 2012

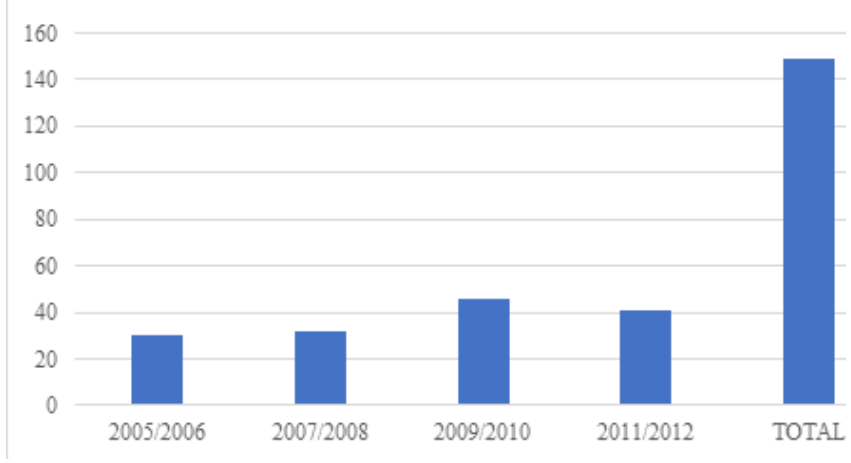

\section{Fonte Autor/ 2018}

Os processos entre 1997 e 2004 engrossaram as fileiras do biênio 2005/2006. Outrossim, verifica-se uma tendência do aumento de processos à medida que o tempo vai passando, apenas não acontecendo no biênio 2011/2012.

O número de 149 processos corresponde ao que foi encontrado nos períodos estudados. Vale lembrar de que os sites dos tribunais se caracterizam por um dinamismo, cujos critérios para alimentação do sistema precisam ser oficialmente explicados pelos gestores dos sistemas.

Ao longo do trabalho de levantamento realizado em três período distintos, constataram-se certas situações curiosas: processos encontrados em um primeiro levantamen- to para o biênio de cobertura desapareciam em outra fase de levantamento. Também para biênios cujos processos já haviam sido levantados, outros processos eram encontrados posteriormente. Como o interesse sempre foi esgotar todas as alternativas de 
identificar os processos de racismo, dando para a base de dados uma natureza censitária, tais situações traziam dificuldade para o desenvolvimento do trabalho.

Para dar mais confiança à base e ao universo de dados coletados, os extratos de andamento dos processos levantados foram inseridos no Sistema Juris. Como se sabe, consta neste documento da data e horário da pesquisa feita. Assim, além do registro de controle próprio, a pesquisa passou a ter o registro oficial do momento de levantamento da informação.

O resultado das demandas em relação à parte está distribuído para cada biênio na forma abaixo:

Tabela 1: Resultado por competência penal/biênio

\begin{tabular}{|l|l|l|l|l|l|l|l|l|}
\hline COMPETÈNCIA & VÍTIMA & $\%$ & RÉU & $\%$ & S/I1 & $\%$ & TOTAL & $\%$ \\
\hline PENAL (2005-2006) & 11 & $37 \%$ & 15 & $50 \%$ & 4 & $13 \%$ & 30 & 100 \\
\hline PENAL (2007-2008) & 9 & $28 \%$ & 23 & $72 \%$ & 0 & & 32 & 100 \\
\hline PENAL (2009-2010) & 26 & $57 \%$ & 17 & $37 \%$ & 3 & $6 \%$ & 46 & 100 \\
\hline PENAL (2011-2012) & 19 & $46 \%$ & 13 & $32 \%$ & 9 & $22 \%$ & 41 & 100 \\
\hline TOTAL & 65 & & 68 & & 16 & & 149 & \\
\hline$\%$ & $44 \%$ & & $46 \%$ & & $11 \%$ & & $100 \%$ & \\
\hline
\end{tabular}

Fonte: Autor, 2018.

Os dados desagregados por biênio revelam que as vítimas são derrotadas nos dois primeiros, enquanto os réus passam a perder nos dois últimos. No cômputo total dos processos, os réus conseguem uma ligeira vantagem de vitórias, correspondendo $46 \%$ dos processos válidos, enquanto as vítimas $44 \%$.

A vantagem dos réus no cômputo geral é obtida graças ao alto escore de $72 \%$ dos casos no biênio 2007/2008.

O levantamento dos processos revelou objetivamente que as bases de dados nos sites dos tribunais de processos de 20 grau não correspondiam à totalidade dos que foram concluídos nos biênios pesquisados pelos tribunais estudados. Outrossim, a consulta a escritórios de advocacia especializados no tema de violência racial, como o Gele- désInstituto da Mulher Negra, indicou que importantes processos patrocinados por seus advogados não estavam no sistema do tribunal do estado São Paulo, quando os levantamentos foram feitos. Um caso emblemático de crime de racismo, o de Gisele Ferreira e Neusa Nascimento ${ }^{12}$, que chegou à Comissão Interamericana de Direitos Humanos, sob acusação de violação do direito ao devido processo legal pela demora injustificável da demanda por esse Tribunal, não

${ }^{12}$ Cf. http://www.cidh.org/annualrep/2006port/BRASIL.1068.03port. htm . O caso das senhoras Nascimento e Ferreira tramitou na justiça penal do estado de São Paulo, capital, e compreendeu crime baseado no artigo 40 da lei 7. 716/89, ou seja, óbice ao emprego em razão da cor das vítimas. 
estava no sistema quando do levantamento dos dados, apesar de já ter transitado em julgado.

A não presença de processos da assistência judiciária do Geledés, uma das principais entidades de proteção ao direito de pessoas vítimas de violência racial, demonstrou que o sistema de alimentação do tribunal de justiça de São Paulo não alimentava automaticamente todos os processos sobre o tema.

Em outros estados, situação semelhante acontece. Ao testar o nome de advogados conhecidos de outras entidades do Movimento Negro, que faziam acompanhamento de casos de racismo, a frequência de casos no banco de dados dos respectivos tribunais foi insignificante. Em Santa Catarina, foi encontrado apenas um processo ${ }^{13}$ acompanhado pelo SOS Racismo do Núcleo de Estudos Negros. Na Bahia, onde desde 1997 funciona uma Promotoria ${ }^{14}$ especializada em casos dessa natureza, apenas foram encontrados dois processos. Processos assistidos por advogados do Afro Gabinete de Articulação Institucional e Jurídica, AGAN$J U$, tampouco foram encontrados no sistema do tribunal baiano.

A ausência de processos emblemáticos fortalece a tese de que nos sistemas de web não há alimentação automática, apesar do emprego de tecnologia cada vez maior por parte dos tribunais no processamento de suas demandas. As razões para isto não são dadas pelos órgãos do Judiciário.

O fluxo processual tende a diminuir à medida que sucedem etapas. A quantidade de notícia crime, que chega à delegacia e ao Ministério Público, é maior que a quan-

\footnotetext{
13 O processo presente na base foi o de número 20030043535 que correu na 2a Vara Crime da Capital.

14 Em 2017, Promotoria completou 20 anos (Cf. https://www.mpba. mp.br/noticia/36367).
}

tidade de demandas judiciais que chegam às Varas, e, por sua vez, o número de ações que chega até a análise dos juízes de segundo grau é ainda menor. Entretanto, esta conclusão, produto do reconhecimento de que número de processos descresse na proporção inversa ao aumento da formalidade e da complexidade do rito processual, não justifica que o número de processos seja tão reduzido na base de dados dos tribunais no Brasil.

A disposição diminuta de casos de racismo no banco de dados dos sites dos Tribunais e a ausência de processos de escritórios importantes de defesa de direitos da população negra trazem inquietação sobre a forma de alimentação do sistema. Perguntas surgem diante da ausência de posições oficiais. A alimentação é aleatória? Existe algum critério para inclusão dos processos? Por que casos de escritórios de entidades importantes não aparecem no banco dedados?

São perguntas que este artigo não tem a presunção de responder de maneira peremptória. Entretanto, algumas considerações podem ser alcançadas, tendo como ponto de continuidade o que será trabalhado nas seções seguintes a partir da análise de algumas variáveis e decisões coletadas na pesquisa.

\section{EXPLICANDO A TENDÊNCIA PELA PERSPECTIVA DAS HIERARQUIAS}

O resultado favorável aos réus encontrado na pesquisa quantitativa encontrou consonância ao sentimento dos grupos de ativistas e advogados da causa antirracista: réus são mais vitoriosos do que as vítimas. Entretanto, a pequena diferença no cômputo final, graças à mudança da tendência para absolvição, chamou atenção. A expectativa

CRIMES DE RACISMO ANALISADOS NOS TRIBUNAIS 
era que houvesse uma margem mais expressiva.

Os dois biênios iniciais (2005 a 2008) foram objeto de duas publicações (Costa, 2008 e Costa \& Carvano, 2011). Estes trabalhos tiveram algum tipo de repercussão em meios midiáticos. Publicação de grande circula- ção nacional, como Revista Isto é15 expôs a condição de desvantagem das vítimas de racismo e a decepção com a abordagem do judiciário na análise dos casos. Do mesmo modo, o tema foi objeto de pesquisa de outros(as) pesquisadores(as) ${ }^{16}$.

O Judiciário sob os holofotes da mídia parece ter despertado em relação ao peso que aquelas ementas largadas nos bancos de dados e disponíveis por buscas poderiam impactar na sua imagem. A redoma impermeável do Judiciário estava sendo transpassada, pois uma radiografia estava sendo feita e que revelava uma situação desfavorável às vítimas de maneira expressiva.

Parece que o Judiciário conseguiu rapidamente reagir quanto aos processos sobre racismo em seus bancos de dados. As bases passaram a ter um conjunto de processos em que as vítimas eram exitosas17. A reação do Judiciário atrapalhou de certa forma a continuidade de pesquisas centradas em trato quantitativo, tendo bases virtuais dos

\footnotetext{
${ }_{15}$ Cf. https://istoe.com.br/138230_RACISMO+NOS+TRIBUNAIS/ . Também outras publicações em anos posteriores como do Correio Braziliense (a matéria ganhou o prêmio Vladmimir Herzog de Anistia eDireitos Humanos em 2015. Cf. https://www.correiobraziliense.com br/app/noticia/cidades/2015/09/30/interna_cidadesdf,500783/correio-ganha-premio-de-direitos-humanos.shtml), Portal IG (Cf. https://ultimosegundo.ig.com.br/brasil/2014-03-21/falta-de-transparencia-da-justica-prejudica-acesso-a-dados-de-violencia-racial.html) deram visibilidade ao tema, mostrando a situação desfavorável que vítimas de racismo passavam nos tribunais brasileiros.

${ }^{16}$ Cf. MACHADO, Marta; RODRIGUEZ, José e PUSCHEL, Flávia. A juridificação do racismo: uma análise de jurisprudência do TJ de São Paulo. In Artigos Direito GV (working papers), nov. 2007. Disponível no site: http://bibliotecadigital.fgv.br/dspace/handle/10438/2775 acessado em 20 de setembro de 2012.

${ }^{17}$ Observa-se que esta constatação foi obtida em 2016 quando man tinha o acompanhamento dos processos pelos tribunais. Entre 2017 e 2018, o Sistema Juris ficou inoperante parcialmente em virtude de necessidade de atualização pela sua migração do site da Universida- de Federal do Rio de Janeiro para a Universidade do Estado da Bahia.
}

tribunais como repositório de informações. Isto pela razão de que a conclusão dos estudos se pautava no apanhado censitário dos processos corresponder à realidade vi- vida por partes e seus advogados. Não teria como existir uma mudança radical se não houvesse algum tipo de manejo, tanto para os casos nos biênios anteriores às publica- ções quanto para os depois da publicação. Se os biênios (2005/2006 e 2007/2008) sob análise denotavam a realidade vivida, os úl- timos (2009/2010, 2011/2012) pareciam não retratar.

Vale registrar de que a jurisprudência disponibilizada pelos Tribunais compreende base de referência para pesquisa de atores judicantes como advogados, promotores e os próprios juízes. Ademais, que a disponibilidade do inteiro teor dos acórdãos permite uma consulta mais analítica, permitindo que aqueles atores possam analisar as melhores estratégias e teses. No momento em que há ausência dos escritórios com maior experiência em casos de racismo, como escritórios de entidades que atuam no tema, vê-se um prejuízo para aqueles que estão buscando informações que ajudem construir suas teses, visando ter êxito em casos de violência racial, sobretudo, as vítimas, historicamente mais desamparadas quanto à assistência jurídica.

O fato de não haver registro na base dos tribunais de processos patrocinados por escritórios militantes obrigou o investimento na análise das decisões disponibilizadas nos sites. As decisões permitem, assim, uma análise mais profunda a partir do levantamento de variáveis censitárias como raça/cor edaquelas relacionadas à ocupação. Estas informações têm o papel de explicar a disposição do Judiciário na figura de seus magistrados quanto aos crimes de racismo. 
A riqueza das informações acessadas e a disponibilidade de decisões em alguns processos deram a chance de avaliar qualitativamente a massa de dados então em mãos da pesquisa e disponível no Sistema Juris. Igualmente, o trabalho de levantamento de processos e seus dados impulsionaram correlações que precisavam ser exploradas. Neste artigo, uma correlação será explorada e que conspira para a tendência em favor dos réus: a condição das partes com o tipo penal entendido como correto pelos juízes.

A tese levantada é fruto da constatação de que os crimes de violência racial, quan- do tem como partes as vítimas negras, são majoritariamente entendidos como injúria. Por outro lado, judeus, que nesta pesquisa são identificados como grupo étnico protegidos em situações de racismo pela lei 7 . $716 / 8918$, quando sofrem crimes raciais, jamais têm as suas demandas qualificadas por esse tipo penal menor. Para o Judiciário brasileiro, racismo previsto no artigo 5ㅇ, inciso XLII da Constituição Federal raramente acontece contra pessoas negras. O gráfico 2 abaixo ilustra a realidade apreendida na pesquisa da análise das 97 decisões:

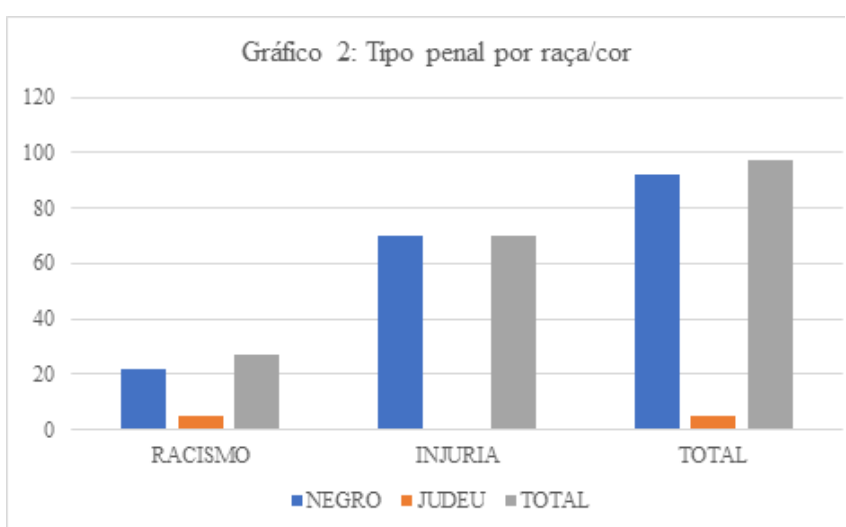

Fonte Autor/ 2017

zodessalei está previsto: "Praticar, induzir ou incitar a discriminação ou preconceito de raça, cor, etnia, religião ou procedência nacional. Pena: reclusão de um a três anos e multa" (grifo meu) (Brasil, 1989).
Os especialistas do direito penal brasileiro, em especial os juízes, creem que a violência racial pode ter trato processual distinto do tipo que está previsto na Constituição Federal como imprescritível, inafiançável e que alcança toda a sociedade. Este tipo é chamado de injúria (Silva, 2001).

Se a vítima de religião judaica é titular do direito de ver sua demanda processada pelo tipo penal racismo, a maioria das vítimas negras somente pode ingressar com ações relacionadas ao racismo na condição de injúria. Do ponto de vista da realidade social, é de conhecimento que a população negra representa os piores indicadores ${ }^{19}$. A população negra, sem exagero, é vista como pária da sociedade. De mesma sorte não sofrem os judeus, pois compreendem uma comunidade no Brasil que goza de prestígio sociale econômico. Vale lembrar que o primeiro caso de racismo ${ }^{20}$ analisado no STF e que manteve a condenação do réu é contra um antissemita que negava a existência do holocausto.

Quando o racismo foi criminalizado e regulamentado logo após a promulgação da Constituição de 1988 pela lei 7. 716/1989, diversos casos que chegavam aos gabinetes dos juízes eram rebaixados à categoria de injúria, tipo previsto no artigo 140 do Código Penal Brasileiro. A injúria até 2009, quando foi alterada pela lei $12.033 / 209^{21}$, era considerada crime de natureza privada, cuja ação

\footnotetext{
${ }^{9}$ Cf. Leão, Cândido, Campos \& Feres Júnior, 2017.

${ }^{20}$ O caso em comento é o Habeas Corpus $82424 / 2003$ que tramitou no STF. Siegfried Ellwanger foi acusado de racismo por publicar material antissemita. A discussão versou sobre o direito de liberdade de expressão. O STF entendeu que havia crime nas manifestações e manteve a condenação por 8 a 3 . Este processo teve a participação de atores judicantes de alto prestígio como o professor da Faculdade de Direito da Universidade de São Paulo, Celso Lafer (2004), que emitiu parecer em forma de amiscus curiae, explicando qual a razão para o entendimento de que manifestações racistas não poderiam ser admitidas sob a justificativa da ampla liberdade de expressão, pois havia proibição legal a manifestações que estimulassem a discriminação contra grupos nacionais. Também anotou Lafer que o conceito de raça transcendia a natureza biológica e correspondia a nível de construção de identidade nacional.
}

${ }^{21}$ Cf. http://www.planalto.gov.br/ccivil_03/_Ato2007-2010/2009/Lei/ L12033.htm acessado em 30/12/2018.

CRIMES DE RACISMO ANALISADOS NOS TRIBUNAIS

BRASILEIROS: o que as características das partes e os interesses corporativos da magistratura podem dizer sobre o resultado desses processos

Cleber Lazaro Juilião Costa 
penal era restrita à iniciativa da vítima por meio da queixa crime ${ }^{22}$ e passível de decadência. Qualquer intervenção por parte do Ministério Público, quanto à propositura da ação, era considerada ilegítima. Vários processos $^{23}$ de racismo ficaram pelo caminho em virtude de seu rebaixamento para o crime de injúria.

O mar de casos de violência racial como injúria pressionou o legislativo a fazer ajustes na lei penal, mas que pouco implicaram em nivelar o crime de injúria como delito de natureza incondicionada, de ação originária do Ministério Público, contra a humanidade, com natureza de inafiançável e imprescritível. As mudanças cosméticas não mudaram na substância o tipo penal entendido pelos juízes como o mais apropriado quando pessoas negras fossem vítimas de racismo, conforme visto no gráfico 2 .

A postura do Judiciário sugere a aproximação da arena jurisdicional com a realidade brasileira. Imersa em um projeto nacional que nega a raça como atributo qualitativo de status, a sociedade brasileira reverencia o ideal de mestiçagem e o discurso idíli- co construindo por autores como Gilberto Freyre $^{24}$ (2001 [1933]).

\footnotetext{
${ }^{22}$ Sistema penal brasileiro dispõe duas modalidades básicas de ação penal: a denúncia, que corresponde a uma ação penal pública, podendo ser condicionada e incondicionada (a 1a depende de representação da vítima e a 2 a não); e queixa crime, ação privada. A denúncia é o tipo de ação cuja legitimidade é dada ao Ministério Público, órgão independente do Judiciário brasileiro, responsável por direitos difusos coletivos. A queixa crime é de exclusividade da vítima (Cf. Capez, 2015).

${ }^{23}$ No caso do presente estudo, quase totalidade dos processos não teve a lei como vigente. Levando em conta que a estratégia de pesquisa determinou temporalmente por biênio o levantamento de casos encerrados e disponibilizados nos sistema, a realidade aqui retratada traduz a maior incidência de situação de rebaixamento com o consequente fim do processo com julgamento de mérito pelos efeitos da decadência, instituto jurídico que estabelece prazo de seis meses para propositura da respectiva ação penal a partir do conhecimento do fato.

${ }^{24}$ Só a título de lembrança, cabe a Gilberto Freyre se opor às ideias eugenistas que orientavam o discurso de vários intelectuais brasileiros, que enxergavam na miscigenação o processo de esterilização intelectual da sociedade brasileira (Cf. Telles, 2012).

A temática sobre relações ganhou destaque quando foram criadas cotas para negros em Universidades públicas. Diversos intelectuais defenderam que tais medidas estavam racializando a sociedade brasileira, cujo projeto de mestiçagem passava a estar em risco (Cf. Feres Júnior \& Campos, 2016).
}

O projeto nacional de um só povo foi estimulado nas duas fases ditatoriais brasileiras, o Estado Novo, que vigeu entre 1937 a 1945, e a da ditadura militar entre 1964 e 1985 . Nestes períodos, a voz do povo negro e de sua Militância foi abafada pela força da baioneta e da ameaça, quando se manifestava no interesse de discutir temas relacionados à discriminação. Koslling (2007, p. 14) destaca que na década de 1940, a "[...]polícia política entendia esses movimentos como subversivos e que levariam a uma crise que poderia gerar conflitos raciais à "democracia racial" brasileira". Hasenbalg e Gonzalez (1981, p. 16) anotam que a violência na Baixada Fluminense na década de 1970 perpetrada pelos esquadrões da morte e de vítimas majoritariamente negras não podia ser denunciada como práticas de perseguição ao povo negro:

[...] os presuntos (cadáveres) desovados pelos justiceiros da nova ordem. Vale notar que $70 \%$ desses justiçados eram negros. Discriminação racial? Era proibido falar dessas coisas naqueles anos de "milagre" uma vez que se estaria ferindo a Lei de Segurança Nacional por crime de subversão.

Os períodos de exceção ao regime democrático brasileiro contribuíram para o conveniente discurso de uma sociedade que havia conseguido êxito nas relações entre as raças que chegaram ao país. Questões relacionadas à forma como a população afro-brasileira chegou ao país, tampouco a ausência de políticas públicas pós abolição conseguiam sensibilizar o Estado e segmentos da sociedade quanto à existência do racismo e da discriminação racial.

Em verdade, a democracia racial do modo brasileiro tem base em um papel funcionalista cuja normalidade social depende de 
cada ator desempenhar o seu papel (Paixão, 2015). O equilíbrio depende que potenciais queixas ou inquietações ao status quo sejam suprimidas ou não levadas a sério. É curioso que até aparentes boas intenções como a iniciativa de Afonso Arinos de Melo Franco, conhecido por propor uma lei que considerava preconceito racial um tipo de contravenção, ou seja, uma modalidade de ilicitude abaixo da natureza de crime, fosse um defensor do antissemitismo e da hierarquia das raças (Ramos, 1995).

A postura de juízes em relação aos crimes de racismo contra a população negra não compreende, assim, um sentimento de indignação como percebido quando são praticados contra judeus. Ao optar por não considerar crimes de racismo como crime regulado pelas leis em que estão regulamentadas as situações de racismo (Constituição Federal, artigo 5o, LXII e lei 7. 716/89 e suas alterações), o juiz brasileiro referenda a ideia disseminada na sociedade brasileira de que não há racismo, pelo menos sofrido contra a população negra.

Esta tendência de negar o racismo revela o distanciamento entre o anseio dos idealizadores da estratégia da criminalização do fenômeno em questão, como uma forma de exercício da cidadania, e os estratos de poder representados na figura dos juízes. $O$ Judiciário demonstra, então, a sua face mais conservadora, refratária às iniciativas de segmentos discriminados e que reivindicam exercício pleno da cidadania e não apenas parte dela.

A marca do conservadorismo no Judiciário fica mais evidente quando se desagrega os dados pelo grau da jurisdição. Na comparação dos resultados de primeira e segunda instância dos processos, levando em consideração apenas o somatório de vitórias identificas e excluídas os "Sem Identificação", vêse que tem uma maior tendência pela absolvição por parte dos desembargadores.

\section{Gráfico 3: Resultado dos processos por grau de jurisdição:}

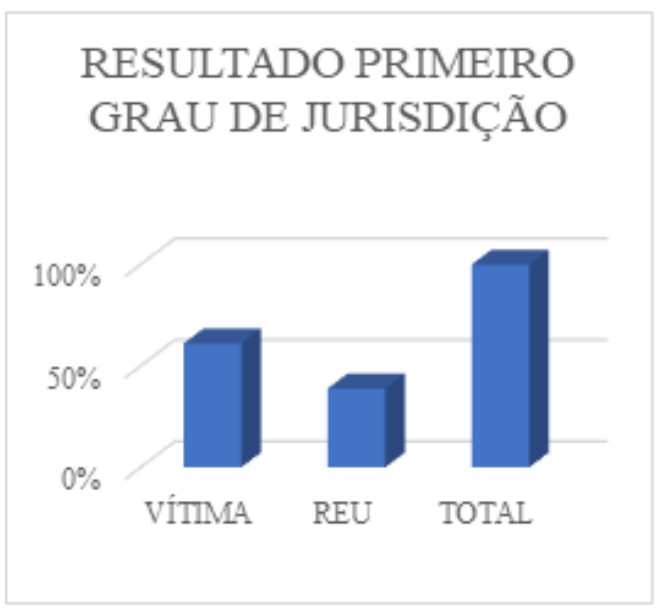

CRIMES DE RACISMO ANALISADOS NOS TRIBUNAIS 
Revista de Estudos Empíricos em Direito

Brazilian Journal of Empirical Legal Studies

vol. $6, n^{\circ}=3$, dez 2019, p. 7-33

Fonte: Autor/ 2018

CRIMES DE RACISMO ANALISADOS NOS TRIBUNAIS

BRASILEIROS: o que as caracteristicas das partes e os interesses corporativos da magistratura podem dizer sobre o resultado desses processos

Cleber Lazaro Juilião Costa 
Nos processos de 10 grau, as vítimas conseguem ter êxito em $61 \%$ dos casos, enquanto os réus $39 \%$. Esta tendência é alterada, quando os processos são objeto de apreciação pelas cortes de $2 \circ$ grau, pois $52 \%$ destas decisões são julgadas em favor do réu, restando $48 \%$ para as vítimas. Como a posição dos juízes de 20 grau corresponde à maior validade no sistema judicial, pois os acórdãos compreendem decisões colegiadas, compostas, no mínimo, por três juízes e são esses acórdãos que ficam depositados nos sistemas virtuais, é fácil deduzir que são essas decisões que serão o objeto de interesse dos atores judicantes, advogados, promotores e dos próprios juízes.

Outrossim, parece que a visão social de hierarquia está mais na mentalidade dos juízes de 2 o grau do que no de 10. Talvez por serem juízes que ingressaram na carreira há mais tempo, revelam um apego a valores postos em xeque pelo movimento social desde quando os direitos de igualdade passaram a constar na ordem jurídica brasileira.

A mesma tendência em absolver réus acusados de racismo não acontece quando sentam-se nos bancos dos réus corpos negros. Estudos há tempos revelam a tendência de condenar os réus quando estes são negros (Ribeiro, 1997 e Adorno, 1994). Ribeiro e Silva (2010) indicam que processos de homicídios desde a fase de inquérito policial até a decisão judicial, fazendo um recorte por cor/raça, as chances de o réu de cor preta ser sentenciado25 em relação ao réu de cor branca aumentam 1, 10 vez; e para níveis de condenação, elas aumentam 1,28 vez em

\footnotetext{
${ }^{25}$ A título de explicação, o processo penal possui fases relativas à continuidade do processo, a fim de que ele alcance a fase final e a fase conclusiva, quando a decisão de mérito definirá se o réu é culpado

comparação com o réu de cor branca.

Outra forma de aferir a característica da parte como potencial elemento para a tensão racial e visualizada nos processos corresponde um olhar atento às ocupações. Os conflitos raciais, que chegam ao Judiciário, têm como protagonistas pessoas que se antagonizam não apenas quanto à raça. $A$ ocupação compreende uma ferramenta de aferição quanto ao status dos litigantes. Da análise apenas das decisões exitosas pelas vítimas, em que foi possível identificar o tipo de ocupação das partes e mensuradas pelos critérios adotados pela Classificação Brasileira de Ocupação (CBO26) adotado pelo Ministério do Trabalho em Emprego, acondição das vítimas ficou assim distribuída:

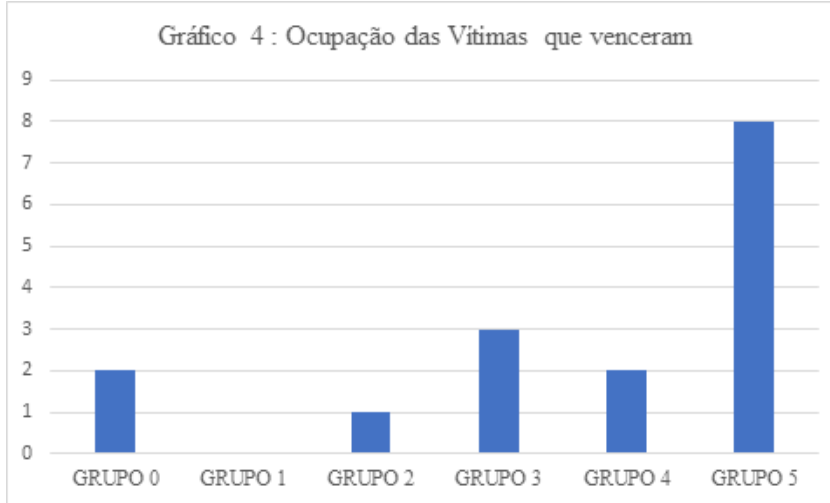

\section{Fonte: Autor/2018}

O critério adotado pela Classificação Brasileira de Ocupações reside em reunir os grupos pelas afinidades de funções, combinadas com nível de instrução. Isto significa encontrar todos os tipos de militares no Grupo 0 (zero), inclusive aqueles das Polícias Militares estaduais. O Grupo 1 abriga os membros superiores do poder público, dirigentes de organizações de interesse público e de empresa e gerentes do setor privado. Já o

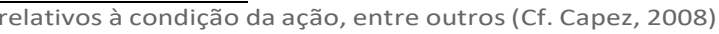


Revista de Estudos Empíricos em Direito

${ }^{26}$ O Ministério do Trabalho e Emprego, visando a uniformização de critérios de ocupação, vem construindo boletins de classificação. Em 2010, foi publicado Classificação brasileira de ocupações: códigos, tí- tulos e descrições, visando atualizar informações sobre as profissões existentes em território nacional (Cf. Brasil, 2012). 
Grupo 2 abriga os profissionais das ciências e das artes, em que estão os professores e profissionais liberais, por exemplo. O Grupo 3 é destinado aos profissionais técnicos de nível médio, enquanto o Grupo 4 corresponde aos trabalhadores de serviços administrativos. Finalmente, o Grupo 5 abriga os trabalhadores dos serviços em geral, vendedores do comércio em lojas, mercados e outras atividades. Este último corresponde aos trabalhadores cuja exigência de formação acadêmica mais elevada é baixa para as ocupações. São atividades que muitas vezes sequer exigem o ensino fundamental primeiro ciclo completo.

O Gráfico 4 revela que o perfil das vítimas tem no Grupo 5 sua maior representativida- de. São ambulantes, auxiliares de serviços gerais, garçons, porteiros em sua maioria. A presença de militares (Grupo 0) restringe-se a Policiais de trânsito que foram constrangidos por motoristas, segundo a análise do conteúdo das decisões. Se os Grupos 2 e 3 têm os seus representantes, não há qualquer vítima que goze do status de ocupar cargos como de executivos, representantes de cargos públicos majoritários ocupantes do Grupo 1. Tampouco membros da magistratura e do Ministério Público são partes na condição de vítimas de processos de violência racial.

Quando a atenção se dirige aos réus, entretanto, o cenário muda significativamente como está ilustrado no gráficoabaixo:

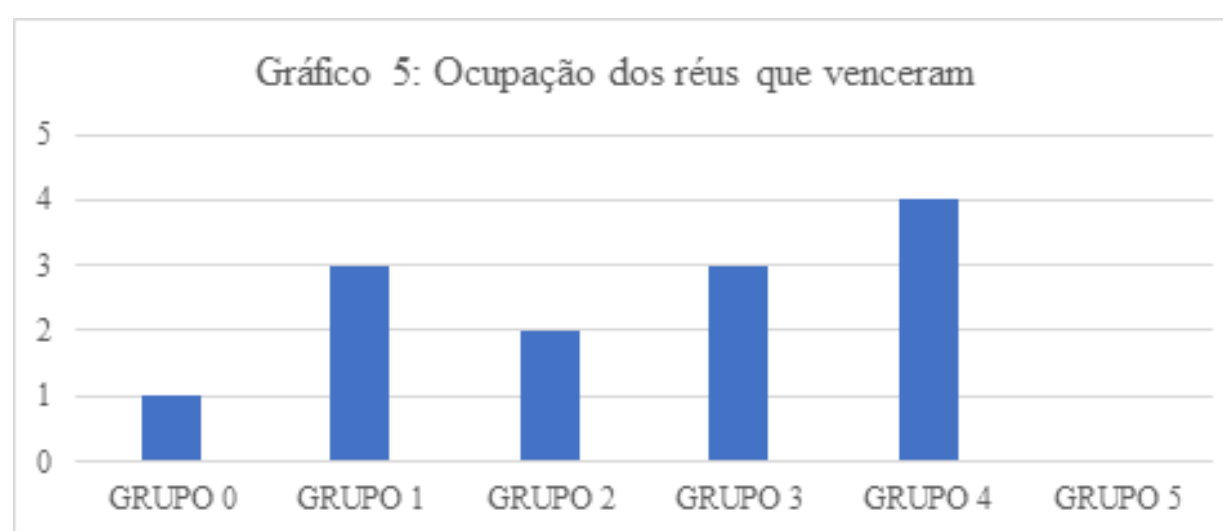

Fonte: Autor/ 2018

Não existem réus acusados de violência racial que ocupem o grupo 5, o de condições de status funcional mais baixo. Por outro lado, estão representados entre os militares (Grupo 0), nos Grupos 1 e Grupo 2, onde o nível de instrução é significativamente maior e os cargos correspondem aos mais altos na estrutura funcional do país.
Os Grupos 3 e 4 são bem representados pelos réus, indicando que todos possuem nível médio completo no mínimo. A maior incidência está no grupo 4. A presença de réus nos extratos mais qualificados suge- re também uma condição socioeconômica melhor do que as vítimas que engrossam significativa as fileiras do Grupo 5.

CRIMES DE RACISMO ANALISADOS NOS TRIBUNAIS

BRASILEIROS: o que as características das partes e os interesses corporativos da magistratura podem dizer sobre o resultado desses processos

Cleber Lazaro Juilião Costa 
A análise dos dados sugere que existe, na maioria dos casos, uma diferença socioeconômica entre as partes em benefício do réu. Para estes, a sensação de superioridade traduz-se na liberdade de agir de maneira racista, talvez na expectativa de que nada acontecerá, afinal, o sentido da democracia racial brasileira é a manutenção histórica das condições de subalternidade não superadas até hoje. $O$ ato racista tem como elemento subjacente a expectativa de que haja impunidade.

A impunidade nos casos de racismo tem espaço em dois momentos: o primeiro, quando o ator do ato racista crê seja normal agir de forma discriminatória, pois ele não acredita que a pessoa discriminada goze dos mesmos direitos que ele; e o segundo quando esta sensação persiste depois do crivo jurisdicional quando crimes de racismo ganham outro sentido, reduzindo a gravidade do fato original e o ressignificando como algo apenas dirigido à pessoa agredida.

As práticas racistas objeto da análise jurisdicional compreendem, em sua maioria, manifestações ofensivas não encaradas como ilicitude. Na arte abaixo, estão anotadas as palavras e expressões encontradas nas decisões analisadas contra vítimas negras do sexo masculino:

\section{Nuvem de palavras 1: Expressões e usadas pelos réus contra homens}

Fonte autor/2018

As expressões dirigidas ao homem negro possuem diversos sentidos. Aludem à comparação com animais, e, com este propósito, associam a cor ao cheiro ruim. Não são poucos os casos de puro desprezo. Todas as expressões conotam sentido de superioridade e visam o abalo psicológico, além pretender colocar o negro em seu lugar; aquele lugar que caracteriza a democracia racial: estar abaixo do branco. Igualmente, são ofensas que o (a)

CRIMES DE RACISMO ANALISADOS NOS TRIBUNAIS 
agressor (a) associa à raça/cor da vítima.

Guimarães (2000) considera que os instrumentos de humilhação visam o afastamento do insultador em relação ao insultado. Esta posição de superioridade do agressor reside na condição social, econômica ou mesmo simbólica.

Não diferente são as ofensas dirigidas à mulher negra. Chama atenção o uso de ex- 
pressões que fazem referência à promiscuidade e o pouco valor para relações afetivas estáveis e com planejamento de se formar uma unidade familiar. Ademais, a ofensa às representatividades religiosas das mulheres de santo são outras manifestações frequentes nos conflitos raciais. São expressões que revelam a desvalorização da mulher negra.
Tanto para homens quanto para mulheres, a desumanização faz parte do processo de agressão. $O$ insulto está sempre dentro do sentido discriminatório da prática de racismo.

Abaixo, estão anotadas as palavras e expressões encontradas nas decisões analisadas contra vítimas negras dosexo feminino:

\section{Nuvem de palavras 2: Expressões e usadas pelos réus contra mulheres:}

Fonte autor $/ 2018$

O conjunto de instrumentos ofensivos e discriminatórios possui uma larga difusão no cotidiano da realidade brasileira. Se para muitos negros e negras correspondem à ilustração de racismo que precisavam ser impedidos pela lei, para muitos, por outro lado, da sociedade brasileira, não passam de brincadeiras de mau gosto com o intuito apenas de ofender a imagem da pessoa ofendida.

Essas ofensas são consorciadas com impedimentos, preterições, exclusões e outras formas que direta ou indiretamente têm como objetivo colocar a vítima no lugar que o (a) agressor (a) entende que lhe se seja de fato. Daí o seu sentido de imposição hierár-

CRIMES DE RACISMO ANALISADOS NOS TRIBUNAIS 
quica própria do entendimento que se tem sobre racismo. Vale lembrar que são práti- cas feitas por pessoas que se encontram em posições funcionais ou sociais mais eleva- das, capazes, portanto, de agir em prejuízo contra as pessoas agredidas.

Na Convenção Internacional sobre a Eliminação de todas formas de discriminação racial, está previsto no artigo 1 a seguinte definição, ratificado pelo Brasil pelo Decreto 65.810 de 8.12.1969:

Nesta Convenção, o termo "discriminação racial", deve significar qualquer distinção, exclusão, restrição ou preferência basea- da em raça, cor, descendência ou origem 
nacional ou étnica que tenha como propósito ou efeito anular ou restringir oreconhecimento ou gozo ou exercício sobre um mesmo plano (em igualdade de condição) de direitos humanos e liberdades fundamentais nos campos político, econômico, social, cultural ou qualquer outro campo da vida pública ${ }^{27}$.

Vale lembrar que essas ofensas acontecem em ambientes de convivência residencial, de lazer e, sobretudo, profissional. Isto quer dizer que os atos racistas são usados como expedientes desqualificantes e implicam em uma forma de coação, visando, na maioria das vezes, o gozo de privilégios questionados pelas pessoas que são agredidas.

Apesar do conjunto de elementos potenciais para a interpretação jurisdicional de casos de racismo, a posição dos juízes é pouco sensível a esses elementos. De fato, a realidade social pautada na hierarquia racial tácita e expressa por diversas formas apare- ce nas decisões dos processos.

Se é racismo ou injúria compreende a centralidade da discussão. Esta diz respeito ao mundo jurídico forjado pela sociedade sem qualquer preocupação com as consequências que uma mudança de tipo penal pode implicar no resultado e na sensação de justiça sendo feita ou não. Apesar das ofensas estarem carregadas de senso de superioridade, elas não são consideradas racismo e sim injúria.

Nesse sentido, essa percepção cerrada às reivindicações de cidadania plena do Movimento Negro encoberta a sensação social de que racismo existe em outro lugar não no Brasil e quando existe apenas em situações em que judeus sejam vítimas. A tabela abaixo ilustra algumas manifestações dos juízes para entender que racismo é injú- ria, tipo penal que não possui a mesma dimensão de sentidos do que está previsto na Constituição brasileira:

\begin{tabular}{|l|l|l|}
\hline \multicolumn{3}{|l|}{ Tabela 2: Manifestações dos juízes acerca do tipo penal correto } \\
\hline Ocupação/ Cor & ANO & EXCERTO DO ACÓRDÃO \\
\hline SI/ Negro & 2008 & $\begin{array}{l}\text { “Os fatos narrados não se amoldam ao tipo penal destacado no art. } 20 \text { (...) mas ao tipo injú- } \\
\text { ria” }\end{array}$ \\
\hline SI/Negro & 2009 & “(...) impossível falar em crime de racismo” \\
\hline Coveiro/Negro & 2006 & $\begin{array}{l}\text { “(...) não há dúvida de quem ofendeu verbalmente a pessoa do ofendido cometendo, ao } \\
\text { meu sentir, injúria qualificada pelo preconceito” (grifo meu) }\end{array}$ \\
\hline Vizinha/Negra & & “(...) desclassificação da conduta (...) para a prevista no art. 140” (grifo meu) \\
\hline SI/Negro & & “Não se trata de crime de racismo” \\
\hline SI/ SI & 2010 & “(...) somente poderia se perfectibilizar no crime de injúria racial” \\
\hline SI/Negro & 2009 & “Reconhecimento de ofício extinção da punibilidade” \\
\hline Ambulante/Negro & 2010 & $\begin{array}{l}\text { “Ocorre que o tipo de injúria somente se procede mediante queixa (...) inevitável que se } \\
\text { reconheça a decadência } 8 \text { ” }\end{array}$ \\
\hline $\begin{array}{l}\text { Colega de trabalho/ } \\
\text { Negro }\end{array}$ & 2012 & $\begin{array}{l}\text { “Contudo que só o racismo é imprescritível, reconheça-se, de ofício, a prescrição da preten- } \\
\text { são punitiva” (grifo meu) }\end{array}$ \\
\hline
\end{tabular}

Fonte: Autor, 2018.

${ }^{27}$ Tradução para o seguinte trecho: In this Convention, the term "racial discrimination" shall mean any distinction, exclusion, restriction or preference based on race, colour, descent, or national or ethnic origin which has the purpose or effect of nullifying or impairing the recognition, enjoyment or exercise, on an equal footing, of human rights and fundamental freedoms in the political, economic, social, cultural or any other field of public life.
${ }^{28}$ A título de informação, decadência compreende um efeito jurídico que compreende a perda do direito de ação pela demora de promover a ação penal. Os casos de injúria racial devem ser encaminhados à justiça no prazo máximo de 06 (seis) meses do conhecimento do fato. Quando um processo de racismo, fundando na lei 7.716/89, é rebaixado para injúria racial (art. 140, par. $3^{\circ}$ do Código Penal) geralmente já se passaram osseis meses.

CRIMES DE RACISMO ANALISADOS NOS TRIBUNAIS

BRASILEIROS: o que as características das partes e os interesses

corporativos da magistratura podem dizer sobre o resultado

desses processos

Cleber Lazaro Juilião Costa 
Os trechos acima mostram situações de vítimas que ingressaram com ações fundadas na lei 7.716/89, em que estão tipificados os crimes de racismo. A escolha da vítima e seu patrono em classificar como racismo compreende para o judiciário brasileiro geralmente uma maior chance de ver a demanda perdida pela mudança do tipo penal para injúria. Em todos casos em destaque, houve o encerramento da ação judicial, mesmo quando havia certeza de que ofato discriminatório estava comprovado, como no caso em que a vítima trabalhava como coveiro (veja ocupação Coveiro/Negro, linha $3)$.

Um dado relevante dos excertos acima compreende na facilidade dos crimes tipificados no artigo 20 da lei 7. 716/89 sofrerem a alteração técnica para injúria. A literatura especializada acredita que o tipo penal do artigo 20 é aberto, devendo sua definição objetiva de casos ser definida pela jurisprudência (Silva, 2001). Esta brecha normativa confere aos atores judicantes entenderem que quando a situação for descrita no citado artigo de que o crime deve ser considerado como injúria. Pouco importa na existência de materialidade do fato e a consequente decadência pelo decurso do prazo de seis meses de proposição da ação.

O sentido de justiça esvai à medida que a vítima vê na condução judicial a mudança do tipo penal. Pouco importa se háidentificação do fato delituoso e a matéria da definição do tipo está condicionada ao entendimento do juízo que poderia dar seguimento como crime de racismo. O resultado é o sentimento de impunidade.

Ter o direito penal como ferramenta de conquista de direito mostra ser algo paradoxal. Ao mesmo tempo que se pauta em uma forma de convocar o Estado quanto à sua atribuição de proteger direitos violados, esta estratégia depara-se em um sistema penal que foi feito para reprimir aqueles que hoje clamam por sua tutela.

A avalanche de casos considerados de injúria revela a falta de reconhecimento por parte dos juízes do propósito em criminalizaro racismo no Brasil, conquista do Movimento Negro. Como práticas cotidianas nas dinâmicas sociais, a sua criminalização compreendeu a possibilidade de o Brasil repensar a forma como vem tratando parte significativa de sua população. O advento da democracia com a Constituição de 1988 compreendeu o marco para esta mudança.

No entanto, o pacto formal não ganhou musculatura nas dinâmicas funcionais que repercutem na ação institucional na figura do Judiciário. A condição de maior vulnerabilidade da população negra, a principal cliente de casos dessa natureza, traduz-se em menor interesse jurisdicional em fazer justiça. Parece que os juízes são sensíveis às posições do establishment sobre a necessidade de manter tudo do jeito que sempre foi: cidadania para uns, não para todos.

Esta tese ganha mais força quando se dirige atenção aos elementos a disposição dos juízes. Sugestão desenhada na seção seguinte.

\section{O MUNDO DOS JUÍZES E O SEU IMPACTO NOS PROCESSOS DE RACISMO}

Geralmente, a análise sobre a atuação de juízes em casos de racismo dirige atenção ao entendimento que estes fazem entre o fato delituoso e o tipo penal (Machado et al, 2015). Este tipo de abordagem articula um conjunto de elementos técnicos do direito. De forma diferente, o presente estudo bus-

CRIMES DE RACISMO ANALISADOS NOS TRIBUNAIS

BRASILEIROS: o que as características das partes e os interesses corporativos da magistratura podem dizer sobre o resultado desses processos

Cleber Lazaro Juilião Costa 
ca consorciar a ideia de que juízes mobilizam o conteúdo jurídico buscando atender seus interesses de acordo com o ambiente funcional e social em que estão inseridos (Epstein, Landes \& Posner, 2013).

Pensar no comportamento dos juízes pela primeira abordagem corresponde entender as interpretações sobre assuntos jurídicos, como se o tipo certo é injúria ou racismo, se a lei antirracista é eficaz e no que ela pode ser aprimorada ${ }^{29}$, por exemplo. É possível, entretanto, investir na análise sobre os juízes enxergando-os mais como pessoas e meros trabalhadores do que como a personificação da justiça, ou seja, são movidos por atendimento de interesses pessoais que possam lhes dar mais tempo em sua vida pessoal, mais dinheiro e mais prestígio, por exemplo.

Os juízes estão inseridos em um contexto de tensões e de interesses. Esta realidade não passa despercebida aos olhos dos magistrados. O lobby e a pressão podem existir, e movimentos de cada parte podem pesar na hora de ser proferido o julgamento. Nos casos estudados, o resultado da análise das variáveis combinado com os tipos penais ilumina a tese de que os juízes compartilham das percepções sociais de uma democracia racial pautada em hierarquia e em status rebaixado da população negra em relação a direitos.

Pensar o judiciário como ambiente de interesse exige iluminar elementos que estão presentes no contexto do desenvolvimento das demandas, mas que aqui são tratadas com outra atenção. Já se sabe de que, nos anos estudados, as vítimas negras perderam mais do que ganharam, de que a maioria

${ }^{29}$ Machado, Silva \& Ferreira (2015) desenvolvem uma interessante pesquisa sob esta perspectiva, fazendo um preciso estado da arte sobre estudos acerca da atuação dos juízes e legislação antirracista. dos casos de racismo contra negros é tratada como injúria; por outro lado as vítimas judias têm a suas demandas concluídas como crimes de racismo, além de serem exitosas em todas elas. Ademais, as tensões raciais narradas nas decisões revelam a existência de uma hierarquia funcional ou simbólica que traduzem a realidade de desprestígio da população negra. É um retrato social do qual o Judiciário em suas decisões parece não discordar.

Há uma expectativa de que a tendência para a manutenção desse quadro não sofra interrupção, pois acarretará consequências na figura de diversidade de teses em um campo e, por conseguinte, mais trabalho. A necessidade de mais trabalho estará nas mãos de quem optar por não aderir à tendência. Como um sistema, a justiça compreende um entrelaço de atos: se o juiz de primeiro grau pode ter a sua sentença modificada ou revisada, por sua vez, o desembargador que relata o caso pode ter a sua tese mantida ou reprovada pelos seus pares.

Assim, a escolha pela tendência poderá dar ao magistrado a possibilidade de alcançar as suas metas mais rapidamente. Vale lem- brar de que a Justiça brasileira valoriza mui- to na atuação de magistrados que tenham produtividade, ou seja, esvaziem a pauta de trabalho dentro dos prazos estipulados ${ }^{30}$. Ora, ao alcançar essas metas, o (a) magistrado poderá ser premiado, seja funcionalmente, seja pessoalmente.

A forma de mensuração de mais trabalho, dirigindo-se para a divergência, ou menos trabalho, mirando-se para a tendência do entendimento do tribunal, compreende analisar o conteúdo judicial dentro dos ele-

${ }^{30}$ Analisando o Justiça em Números (BRASIL, 2018), percebe que a tônica dos informes na parte de atuação funcional dos juízes centra esforço no cumprimento de metas, sob a justificativa de demonstração de eficiência da máquinapública.

CRIMES DE RACISMO ANALISADOS NOS TRIBUNAIS

BRASILEIROS: oque as características das partes e os interesses corporativos da magistratura podem dizer sobre o resultado desses processos

Cleber Lazaro Juilião Costa 
mentos que podem contribuir na fundamentação de uma decisão. A análise dos casos de violência racial a partir das decisões identificou elementos comuns e que constituem conteúdos próprios do mundo jurídico. Os juízes fundamentam as suas decisões usando provas, jurisprudência e doutrina para dizer se condenam ou absolvem. Estes elementos juntam-se ao conteúdo legal, o elemento central do conteúdo decisório. Cada uma delas tem um valor do ponto de vista da construção do argumento e de sua respectiva legitimação. Isto quer dizer que a prova desempenha um papel fundamental na decisão, pois ela funciona como a ferramenta probatória do que se é alegado pela parte autora da ação. Já jurisprudência e doutrina são elementos acessórios, traduzindo-se no interesse de embasar as posições dos juízes na literatura produzida ou por tribunais ou pela academia, respectivamente.

\section{O gráfico 6 traz a codificação do conteúdo probatório.}

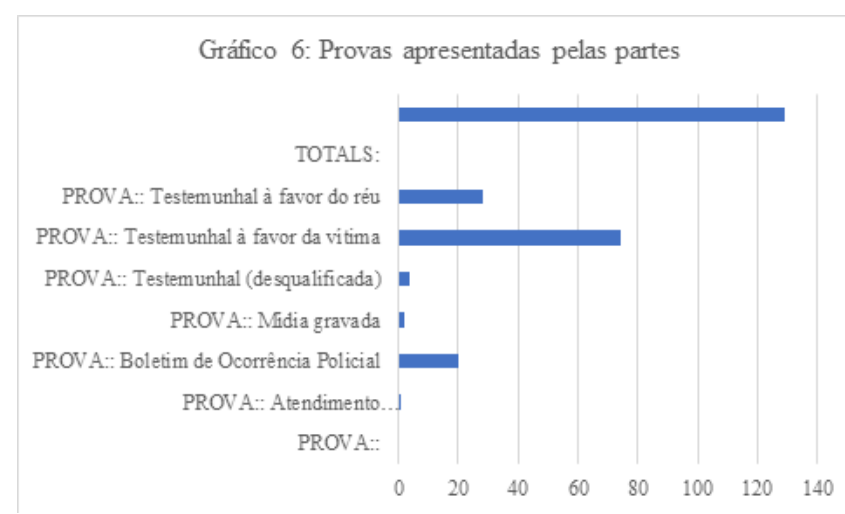

Fonte: Autor/2018

As provas arroladas, à exceção das usadas pelos réus e o atendimento médico que indica a condição de demência de uma muIher acusada de racismo, foram de inciativa das vítimas. Isto corresponde 111 para elas e apenas 29 provas para os réus.

A prova testemunhal é a mais usada no processo. As vítimas conseguiram ter ouvidas na condição de testemunhas 78 pessoas, enquanto os réus apenas 28 foram ouvidas nestas condições. Os juízes ainda desqualificaram 10 testemunhas das vítimas.

Como se sabe, as decisões de 20 grau absolvem $52 \%$ réus e condenam $48 \%$ nas decisões analisadas nos casos. As vítimas usam 2, 8 mais testemunhas do que os réus. Isto significa que o instrumento probatório testemunhal é amplamente usado pelas vítimas, visando demonstrar o fato. Apesar deste expressivo número de testemunhas, do ponto de vista numérico, o seu uso não tem sido suficiente para convencimento do juízo de 2 grau das decisões estudadas.

Como meio de prova, fica evidente, além do maior uso de testemunhas pelas vítimas, de que os juízes de segundo grau buscam fortalecer os seus argumentos informando detalhadamente o que aconteceu através deste meio de prova. Equivalente ao esforço das vítimas, os juízes, que se convencem da existência do fato delituoso, se esmeram em articular o conteúdo das provas para justificar as condenações nos casos de racismo estudados.

Se os juízes precisam das provas para construir um argumento plausível para convencer os seus pares quanto à condenação, quando decidem pela absolvição, preferem usar a jurisprudência. O uso da jurisprudência é fartamente utilizado nas decisões que absolvem os réus. No quadro abaixo, vê-se a distribuição em relação a quem se beneficia com o seu uso. 


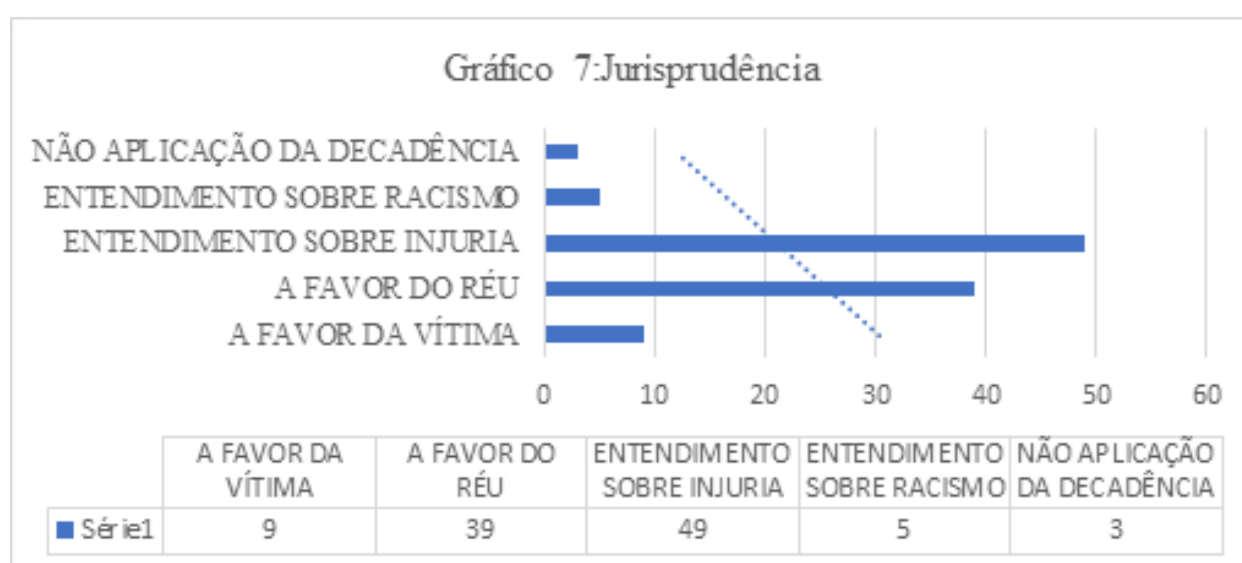

\section{Fonte: Autor/ 2018}

O número de julgados usados como jurisprudência para embasar elementos favoráveis à absolvição é infinitamente maior do que para condenar.

As cinco categorizações da jurisprudência levantada nas 97 decisões foram baseadas nos seguintes critérios: (1) a favor do réu; (2) a favor da vítima; e (3) podendo ser usado tanto em benefício de um quanto de outro.

Juntos "entendimentos sobre injúria" e a "favor dos réus" somam 88 registros, enquanto a "refutação da decadência" e "a favor da vítima" apenas 12. Ademais, o número expressivo de jurisprudências sobre injúria revela a sua grande vantagem em relação ao racismo. Levando-se em conta de que a maioria dos casos estudados foi de vítimas negras, a análise das decisões demonstrou que crime de racismo é artigo raro no sistema judicial brasileiro.

A tabela também indica as jurisprudências que tinham como objeto de análise crimes de injúria e crimes de racismo. A jurisprudên- cia sobre injúria é quase dez vezes mais abundante do que a de racismo, e, nestes casos de uso deste último, tanto pôde servir para fun- damentar condenação quanto absolvição.

A fartura de decisões em formato de jurisprudência nos tribunais e usadas pelos juízes autoriza afirmar que há existência de uma posição objetiva do Judiciário, cuja assertiva é de que crimes racistas devem ser analisados como injúria, quando as vítimas são negras, prescindindo, assim, das características previstas na Constituição de ser um crime inafiançável, imprescritível e contra a humanidade. Esta posição demonstra uma forte tendência judicial que obriga qualquer voto dissidente um esforço argumentativo maior para que consiga permitir o convencimento dos pares de quem está incumbido do relatório.

Por seu turno, o trabalho do juiz, quando opta em analisar detidamente as testemunhas, é maior. Este maior esforço inicia-se na fase de 10 grau. Vale lembrar que na fase de 10 grau, as vítimas ganham mais que os réus. Isto significa que muito do conteúdo usado pelos juízes de $1 \circ$ grau foi aproveitado pelos de $2 \circ$ grau quando da confecção do relatório, sobretudo, as evidências da materialidade dos fatos, pois não como há condenar sem existir provas dos fatos. 
O juiz relator maneja as informações alusivas à prova de acordo com a linha de entendimento que constrói para chegar ao resultado. Este, quando se convence que o réu é culpado, renova o uso das provas testemunhais como parte da estratégia de convencimento dirigida aos seus pares e quaisquer pessoas que tenham acesso ao seu texto. Em verdade, tanto o juiz que absolve, quanto o que condena precisam construir argumento que vise convencer. Mas no caso de crimes raciais, fica evidente de que o juiz que condena empenha um esforço maior, explorando as provas testemunhais em comparação às categorias jurisprudência e doutrina.

Como se vê no gráfico 7, a maioria do conteúdo jurisprudencial encontrado dirigia-se a construir argumento de absolvição na figu- ra de jurisprudência. Do ponto de vista estritamente do direito, a jurisprudência foi usada tanto em decisões condenatórias quanto absolutórias. Entretanto, a presença de jurisprudência que visava ilustrar o entendimento sobre injúria, mormente quando as ações eram de racismo, indicava o propósito absolutório. Por este diapasão, não havia necessidade de usar provas, quando a mudança de tipo penal geraria, inevitavelmente, a extinção do processo com julgamento de mérito pela decadência, ou seja, o processo acabaria para sempre sem possibilidade de nova ação por parte da vítima.

A prova compreende o meio mais objeti- vo de condenação no processo. No penal, orientado pelo princípio de que a dúvida deve beneficiar o réu, a necessidade de instrumentalizar conteúdo quando se pretende condenar torna-se imperioso. Entretanto, a posição dos juízes em casos de racismo quanto ao tipo penal e à relativização do fato delituoso em si aumentam, em progressão geométrica, a necessidade de construir uma tese baseada em provas. Da análise das decisões ficou evidente de que o esforço de articulação das provas com o conteúdo jurídico coube aos juízes que condenaram. Estes trabalharam mais certamente, pois enquanto enumerar jurisprudência corresponde a uma ação mecânica, explicar as provas trazidas pelas partes exige esforço intelectual e tempo para que haja perfeita compreensão e convencimento.

A medida de mais trabalho começou nas decisões de 10 grau, onde as vítimas foram mais exitosas, e o uso de provas foi feito para provar o alegado. Por outro lado, a mudança da tendência para a absolvição em 20 grau revelou o maior uso da jurisprudência, sobretudo para aludir as características do tipo penal injúria. Com efeito, a utilização da jurisprudência em maior quantidade e menos de provas nesse momento processual redunda na constatação de menos esforço.

Outro recurso usado por juízes e que pode relevar qualitativamente o uso de mais esforço quanto de menos compreende o que está anotado na decisão que diz respeito à doutrina, expressão usada no mundo jurídico para mencionar a produção acadêmica. No gráfico 8 abaixo, há uma discriminação da literatura usada pelos juízes relatores pela associação de vitória seja do réu, seja da vítima:

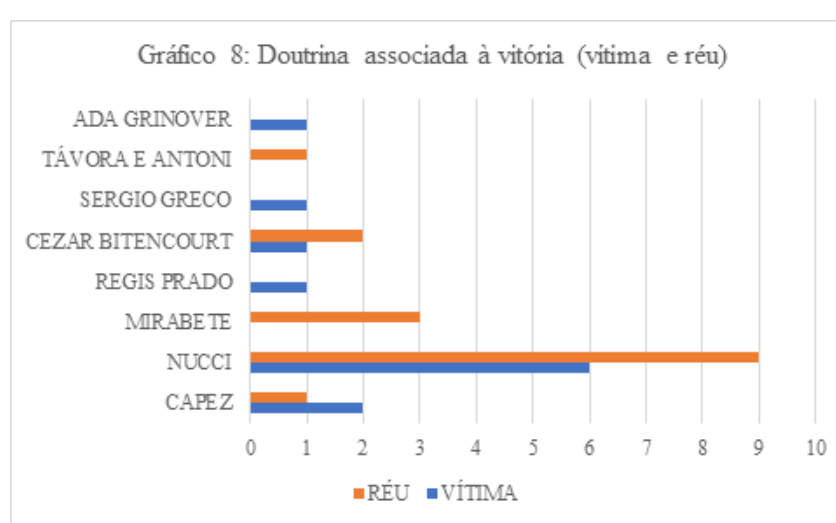

Fonte: Autor/2018

CRIMES DE RACISMO ANALISADOS NOS TRIBUNAIS

BRASILEIROS: o que as características das partes e os interesses corporativos da magistratura podem dizer sobre o resultado desses processos

Cleber Lazaro Juilião Costa 
O levantamento da produção acadêmica trabalhada nas decisões tinha como propósito analisar o grau de complexidade dessas referências. Isto quer dizer, encontrar material tanto jurídico quanto não jurídico. Quanto a este último, textos que explicassem a temática racial no Brasil, que trouxessem reflexão sobre a realidade brasileira por uma perspectiva histórico e social. Enfim, conteúdo que ajudasse a entender o fenômeno do racismo no Brasil e que pudesse ser articulado com o conteúdo propriamente jurídico.

Das referências extraídas e discriminadas no gráfico 8, nada foi encontrado com conteúdo além do jurídico. Por outro lado, cânones do direito penal, como Greco, Bitencourt, Mirabete, Nucci e Capez, têm grande valia na elaboração de decisões. Destaca-se a ubiquidade de Nucci, presente em quase todas as decisões, apesar de sua maior frequência em decisões vencidas pelos réus.

Dos juristas anotados nas decisões, exceto as obras de Grinover e Grecco foram citadas apenas em decisões favoráveis às vítimas. Por sua vez, as de Távora e Antônio, como Mirabete foram referência para absolvições. Os demais foram citados tanto para absolver os réus, quanto para condená-los, o que indica a natureza desses textos serem moduláveis em relação ao que se pretende argumentar.

A ausência de literatura sensível ao tema do racismo e das relações raciais no Brasil revela que ou o judiciário está limitado ao mundo jurídico em seu sentido estrito, ou está influenciado pelo senso comum acerca das relações raciais para fundamentar as suas decisões. Em verdade, a impressão alcançada da leitura das decisões é de que o segundo ajuda a fundamentar o primeiro.
Tanto a jurisprudência quanto a doutrina conferem um toque acadêmico e de erudição à decisão. Entender qual o propósito delas está condicionado ao contexto que se constrói por meio da narrativa feita pe- las provas que são trazidas para o processo. $O$ juiz convencido da materialidade do fato e o papel de se fazer justiça submete-se ao esforço de articular o conteúdo que está a sua mão do jurídico e além do jurídico para fundamentar a sua decisão.

O desafio de construir um entendimento que vai de encontro à percepção social de normalidade sem dúvida exige mais esforço por parte do magistrado. Ele sabe que a sua posição contrária pode ter mais resistência por parte de seus pares, ao contrário de tomar uma decisão que converge com o entendimento social e de membros de sua corporação.

A análise dos dados quanto ao interesse do juiz revela que de fato a opção por absolver casos de racismo implica em aderir a tendência em que há fartura de jurisprudência. Não à toa, diversas decisões absolutórias dispunham de um significativo número de acórdãos colados no relatório, buscando convencer o entendimento que se tinha sobre a natureza do crime de racismo contra negro como crime de injúria.

A tendência pela absolvição e a maneira de encarar o crime de racismo como injú- ria também revelam uma adesão à opinião da sociedade ou de seus segmentos de maior prestígio de que a criminalização do racismo tendo como beneficiários a população negra não foi aceita. Ao se posicionarem que negro sofre injúria e não racismo, apesar de as ofensas trazerem em seu bojo sentimentos de hierarquia, os (as) juízes (as) referendaram o discurso que parece muito 
forte na sociedade brasileira. Vale sempre lembrar que as vítimas perdem mais do que ganham e que desqualificar um crime de racismo para injúria é encerrar o proces- so em virtude dos efeitos da decadência na maioria dos casos.

Evidentemente, a demonstração desse caráter parcial vinculado à pressão social e ao interesse exige cuidado. Interpretar as decisões e construir elementos de aferição são, certamente, parte da receita para uma análise que tem como desiderato influenciar em práticas mais virtuosas e que confiram o mais amplo exercício cívico a todas as pessoas.

O Judiciário, como órgão estratégico para a democracia, precisa abrir espaço para que este debate ganhe força. O maior ganho será para a sociedade e para o próprio Judiciário.

\section{CONCLUSÃO}

O presente estudo teve como propósito investigar se a condição das partes poderia explicar a tendência pela absolvição em casos de racismos. Também analisar o comportamento judicial nesses casos pela perspectiva do interesse, revelando se aquela tendência implicava em menos trabalho para o magistrado. Tanto a condição das partes, quanto o interesse dos juízes foram avaliados em um cenário social de histórica desvantagem da população negra para materialização de direitos.

A possibilidade de constituição desta avenida de pesquisa só foi possível graças à ampliação das atribuições do Judiciário. Como agência que dirime conflitos entre pessoas, o Judiciário passou a receber demandas fruto de conflitos raciais e, a partir desta oportunidade, ser objeto de estudos que pudessem compreender como entende o racismo.

A despeito de representar importante papel para a democracia, o Judiciário ainda carece de mecanismos oficiais de divulgação de seus atos. Tal obstáculo exige que a produção de dados seja feita por cada pesquisador que, por diversas estratégias, tenta acessá-los dos tribunais. Com efeito, uma das formas de tentativa de acesso aos dados tem na internet um meio factível, apesar de cada vez mais sob controle.

A pesquisa pela internet permitiu o levantamento de processos de todas as unidades da federação e a constatação de que os réus são mais vitoriosos do que as vítimas. Entretanto, o número de processos encontrados revelou que os bancos de dados não são alimentados em sua totalidade. Igualmente, o manuseio dos dados revelou que há manipulação de quais processos devem estar no banco de dados dos tribunais. Esta conclusão surgiu ao se constatar que casos assistidos por importantes escritórios de advocacia militantes contra o racismo são minoria no sistema webdos Tribunais.

As decisões penais arquivadas nos bancos de dados dos tribunais e concluídas entre os anos de 2005 e 2012 permitiram uma análise qualitativa pautada na condição das partes. O resultado da leitura desses acórdãos revelou a existência do componentehierárquico nas tensões raciais, seja quanto ao reconhecimento do tipo penal, seja no próprio resultado.

Também fica evidente que para a justiça brasileira racismo não é a regra e sim a exceção. A maioria das decisões ou foi processada como injúria ou foi rebaixada para este tipo penal menor quando os crimes fossem contra negros. Quando a violência racial é

CRIMES DE RACISMO ANALISADOS NOS TRIBUNAIS

BRASILEIROS: o que as características das partes e os interesses corporativos da magistratura podem dizer sobre o resultado desses processos

Cleber Lazaro Juilião Costa 
direcionada contra judeus, estes têm a garantia de que o tipo penal racismo será preservado, pois todos os casos foram assim reconhecidos. Esta situação reflete o reconhecimento que este grupo pode sofrer um mal considerado crime contra a humanidade. Da mesma sorte não gozam pessoas negras quando são discriminadas, humilhadas, impedidas, entre outras formas de discriminação. Os (as) juízes de segundo grau ponderam que a injúria é o tipo penal mais adequado para essas pessoas.

O tipo penal injúria guarda nos processos duas características: rebaixamento à pretensão originária do Movimento Social ao criminalizar o racismo; e, se ela aconteça no curso do processo, a certeza de que o caso terminará sem julgamento de mérito pelos efeitos da decadência. Tanto um quanto outro representam uma derrota, seja sociopolítica daqueles que lutaram pela visibilidade do tema pela criminalização, seja jurídica pela mudança do tipo e a perda do caso.

A hierarquia está presente nos casos contra vítimas negras. A partir da análise das decisões fica patente que a maioria das vítimas ocupa profissões menos valorizadas, cuja exigência de escolaridade média e superior é menor. Já os réus possuem escolaridade mínima de ensino médio e ocupam altos postos funcionais, muitos deles que condicionam o ensino superior completo para o seu preenchimento.

A questão do componente hierárquico traduz-se na manutenção da visão quanto ao sentido da democracia racial: desde que cada uma saiba o seu lugar, tudo está bem. Os juízes parecem consentir esta ideia que teima em subsistir apesar de tantas leis que dizem o contrário fruto da mobilização do Movimento Negro.
A tendência de absolver também possui o componente do interesse dos juízes. Se é uma medida difícil de aferir, ao mesmo tempo, a hipótese de que os juízes agem como indivíduos no seu cotidiano funcional e menos como a personificação da justiça pode explicar quando se observa que juízes que absolvem tendem a trabalhar menos, enquanto os que condenam trabalham mais.

Para o desenvolvimento dessa tese, da análise dos recursos (provas, jurisprudência e doutrina) usados pelos juízes para julgar, constatou-se que a absolvição implicou em um uso maior da jurisprudência. Por outro lado, quando decidia pela condenação, a necessidade de articular as provas arroladas nos autos com a lei e demais recursos disponíveis era maior. Assim, as decisões condenatórias tiveram riqueza no elemento probante, enquanto as de absolvição um oceano de jurisprudência.

A análise da literatura mencionada nas decisões, e conhecida no mundo jurídico como doutrina, evidenciou a exclusividade do conteúdo jurídico acadêmico como base argumentativa. Não há quaisquer registros de textos com preocupação em estudar a sociedade brasileira, relações raciais e racismo.

A combinação de senso comum com a pouca familiaridade dos (das) juízes (juízas) com a temática das relações raciais no Brasil resulta na constatação por meio das decisões de que o Judiciário mantém uma postura conservadora sobre casos de racismo. Pensar em estratégias de mudança desse perfil profissional ascende como algo necessário para o aperfeiçoamento da justiça.

A democracia precisa do direito como dispositivo de previsibilidade do que é possível e o que não é possível. Este limite está es- 
sencialmente pautado na igualdade a acesso a recursos, como o processo legal. Por esta razão, cada vez que o juiz analisar um caso, ele precisa ter um compromisso com as pessoas, buscando o melhor para que os danos supostamente ali apresentados possam ser reduzidos.

A união de tantas peças desse mosaico neste trabalho pretende, assim, contribuir para que haja uma reflexão articulada dos atores judicantes, academia e sociedade quanto ao desenvolvimento de ações que busquem reduzir os danos eventualmente praticados pelo Judiciário em seu cumprimento institucional. A justiça na democracia, que propõe ser inclusiva, precisa romper as barreiras de uma sociedade que guarda valores de hierarquias e não reconhece o direito das pessoas que reivindicam cidadania plena. Assim, o Judiciário precisa fazer a sua parte.

\section{REFERÊNCIAS:}

Adorno, S. (1994) Crime, justiça penal e desigualdade jurídica: mortes que se contam no tribunal do júri. In Revista USP, N. 21.

Brasil. Constituição da República Federativa do Brasil. Disponível em: http://www.planalto.gov.br/ccivil 03/ Constituicao/Constituicao.htm Acessado em 30/12/18.

Lei 7. 716. Disponível em : http://www.

planalto.gov.br/ccivil 03/leis/L7716.htm Acessado em 30/12/2018.

Lei 12.033. Disponível em https:// www.planalto.gov.br/ccivil 03/ ato2007-2010/2009/lei/ I12033.htm .Acessado em 30/12.18

Brasil- Conselho Nacional de Justiça. Censo do Poder Judiciário. Brasília: CNJ. 2014.

Caó, C. A. Justificação: projeto de lei 668/1988. In Diá-

rio de Congresso Nacional. Seção I, p. 2208-2209 de 15 de maio de 1988.

Capez, F. (2006) Curso de processo penal. São Paulo:
(2015) Código penal anotado. São Pau-

lo: Saraiva.

Conselho Nacional de Justiça. (2018) Justiça em nú- meros 2018: ano-base 2017. Brasília: CNJ. 2018. Recu- perado em 02 de outubro de 2019. https://www.cnj. jus.br/wpcontent/uploads/2011/02/8d9faee7812d35a-

58cee3d92d2df2f25.pdf

Costa, C. L. J. e Carvano, M. Resultados de julgamentos dos casos de racismo nos tribunais de justiça e nos tribunais do trabalho. in Paixão, Marcelo e tal (organizadores). Relatório anual das desigualdades raciais. Rio de Janeiro: Garamond. 2012. pp. 260-266.

Costa, C. L. J. (2013) O Supremo Tribunal Federal e o conflito das elites brasileiras: Centralismo Político versus Federalismo. In Cadernos de Ciências Sociais Aplicadas, n. 15, pp. 11-34. Recuperado em 26 de julho de 2016 http://periodicos.uesb.br/index.php/cadernosdeciencias/article/viewFile/4795/4587

Epstein, L; Landes, W.; Posner, R. (2013) The behavior of federal judges: a theoretical and empirical study of rational choice. Cambridge: Havard University Press.

Epstein, L e Knight, J. (2015) Recosidering judicial preferences. In Annual Ver. Political and Sciense. Recuperado em 07 de abril de 2015. www.annualreviews.org Feres Júnior, J. e Costa, C. L. J. (2015) Racial profiling e direitos do cidadão: as contradições de uma política de segurança racista. In Carta Maior de 29 de setembro de. 2015. Recuperado em 20 de outubro de 2016. http://cartamaior.com.br/?/Editoria/Direitos-Humanos/Racial-profiling-e-direitos-do-cidadao-as-contradicoes-de-uma-politica-de-seguranca-publica-racista/5/34623

Feres Júnior, J. \& Campos, L. A. (2016) Ação afirmativa no brasil: multiculturalismo ou justiça social? Lua Nova. Revista de Cultura e Política, p. 257-293.

Freyre, G. (2001).Casa -grande e senzala. São Paulo: Global.

(1990) Sobrados e mocambos: deca-

dência do patriarcado rural e desenvolvimento do urbano. Rio de Janeiro: Record.

Galanter, M. \& Luban, D. (1974) Poetic justice: puniti- ve damages and legal pluralismo. 42, AM. U. L. Rev. 1393, 1406 (Summer 1993). GALANTER, Marc. Why the "haves" come out ahead: speculations on the limits of legal change. In Law and Society Review, vol. 9:1.

(1983) Reading the landscape of dis-

Saraiva.

CRIMES DE RACISMO ANALISADOS NOS TRIBUNAIS

BRASILEIROS: o que as características das partes e os interesses corporativos da magistratura podem dizer sobre o resultado desses processos

Cleber Lazaro Juilião Costa 
Revista de Estudos Empíricos em Direito

Brazilian Journal of Empirical Legal Studies

vol. 6, no , dez 2019, p. 7-33

putes: what we know and we don't know (and think we know) about our allegedly contentious and litigious society. Los Angeles: UCLA Law Review, 31 UCLA 
L. Rev. 4 .

Greco, R. (2007) Curso de direito penal: parte geral, vol. 1. Niteroi: Impetus.

Guimarães, A. S. (2000) O insulto racial: as ofensas verbais registradas em queixas de discriminação. Rio de Janeiro: Estudo Afro Asiáticos, 38. Recuperado em 12 de abril de 2019. http://www.scielo.br/scielo.php?scrip$\underline{\mathrm{t}=\mathrm{sci}}$ arttext\&p

\section{id $=$ S0101-546X2000000200002\&lng=en\&nrm=}

\section{iso\&tlng=pt\#nt04}

ICERD- International Convention on the Elimination of All Forms of Racial Discrimination. United Nations Human Rights/ Office of the High Commissioner. Recuperado em 12 abril de 2019. https://ohchr.org/EN/ Professionallnterest/Pages/CERD.aspx

Hasenbalg, C \& Gonzalez, L. (1981) Lugar do negro. Rio de Janeiro.

Köslling, K. S. (2007) As lutas antirracistas dos afrodescendentes sob a vigilância do DEOPS (1964-1983). Dissertação de Mestrado pela Faculdade de Filosofia, Letras e Ciências Humanas do Departamento de História. São Paulo, São Paulo, Brasil.

Leão, N., Candido, M. R., Campos, L. A. \& Feres Júnior, J. (2017) Relatório das Desigualdades de Raça, Gênero e Classe (GEMAA), n. 1, pp. 1-21.

Jesus, D. (2006) Código Penal Anotado. São Paulo: Saraiva.

Lafer, Celso. (2004) O caso Ellwanger: anti-semitismo como crime da prática de racismo. Brasília a. 41, n. 162 abr./jun. 2004

Machado, M., Rodriguez, J. \& Puschel, Flávia. (2007) A juridificação do racismo: uma análise de jurisprudência do TJ de São Paulo. In Artigos Direito GV (working papers), nov. Recuperado em 20 de setembro de 2012. http://bibliotecadigital.fgv.br/dspace/handle/10438/2775

Machado, M., Silva, N. \& Ferreira, C. (2015) Legislação

antirracista punitiva no Brasil: uma aproximação à aplicação do direito pelos tribunais de justiça brasileiros. In Revista de Estudos Empíricos em Direito, vol. 2, n. 1, jan. 2015, p. 60-92.

Paixão, M., Rosseto, I. e Carvano, Marcelo (organizadores). (2008) Relatório anual das desigualdades raciais. Rio de Janeiro: Garamond.

Paixão, Marcelo et al (organizadores). (2012) Relatório anual das desigualdades raciais. Rio de Janeiro: Garamond.

Paixão, M. (2014) A lenda da modernidade encantada: relações raciais e projeto de Estado- Nação. Curitiba: CRV.

Ramos, A. G. (1995) Introdução crítica à sociologia brasileira. Rio de Janeiro: UFRJ.

Racusen, S. (2000) The Ideology of the Brazilian Na- tion and the Brazilian Legal Theory of Racial Discrimi- nation. Social Identities. Vol. 10: No. 6. 2000

Ribeiro, C. A. C. (1995) Cor e criminalidade: estudo e análise da justiça no Rio de Janeiro (1900-1930). Rio de Janeiro: Editora UFRJ.

Ribeiro, L. \& Silva, K. (2010) Fluxo do sistema de justiça criminal brasileiro. in Cadernos de Segurança Pública. Ano 2, n. 1. Agosto. Recuperado em 20 de setembro de 2012. www.isp.ri.gov.br

Sales Júnior, R. L. (2006) Raça e justiça: o mito da democracia racial e o racismo institucional no fluxo de justiça. Tese apresentada ao programa de pós graduação em Sociologia do CFCH/UFPE-Doutorado). Recife.

Silva Júnior, H. (2002) Direito de igualdade racial: aspectos constitucionais, civis e penais. Doutrina e jurisprudência. São Paulo: Juarez de Oliveira.

SÍNTESE de indicadores sociais: uma análise das condições de vida da população brasileira 2015. Rio de Janeiro: IBGE, 2015. 134 p. (Estudos e pesquisas. Informação demográfica e socioeconômica, n. 35).

Telles, E. (2012) O significado da raça na sociedade brasileira. Princeton e Oxford: Princeton University Press. Recuperado em 22 de junho de 2015 http://www.princeton.edu/sociology/faculty/telles/livro-O-Significado-da-Raca-na-Sociedade-Brasileira.pdf Vianna, L. W., Carvalho, M. A., Melo, M. P. C. \& Burgos, M. B. (1999) A Judicialização da política e das relações sociais no Brasil. Rio de Janeiro: REVAN.

por uma crítica ao pensamento social brasileiro sobre 
Revista de Estudos Empíricos em Direito

Brazilian Journal of Empirical Legal Studies

vol. 6, ํㅜ 3, dez 2019, p. 7-33

Data de submissão: 17/04/2019

Data de aceite: 18/10/2019 